\title{
19
}

\section{Medieval Animals in Middle-earth}

\author{
J.R.R. Tolkien and the Old English and Middle English Physiologus
}

\author{
Thijs Porck
}

This contribution considers the influence of two medieval English texts on Tolkien's fictional writings: the Old English and Middle English versions of Physiologus. As I will demonstrate, Tolkien was intimately familiar with the medieval bestiary tradition: he wrote two parodical bestiary entries and his description of spiders in The Lord of the Rings may have drawn inspiration from the entry for the spider in the Middle English Physiologus.

Cet article considère l'influence de deux textes médiévaux sur les textes fictifs de Tolkien: les versions en vieil anglais et en moyen anglais du Physiologus. Comme je vais le montrer, Tolkien était familier de la tradition du bestiaire médiéval: il a écrit deux descriptions parodiques de bestiaire et sa description des araignées dans Le Seigneur des anneaux a pu s'inspirer de celle dans le Physiologus moyen anglais.

Middle-earth is rife with animals. A tally by Antje vom Lehn has revealed that J.R.R. Tolkien's The Lord of the Rings makes mention of no fewer than seventyfive different kinds of animals. These animals often help the protagonists in their quest or act as their proxy, visualizing such emotions as fear and discomfort. Other animals, mostly birds, are used for descriptive purposes, e.g., to describe distances travelled ('as the crow flies'), the atmosphere of a location (from the melancholic piping of birds on the way to Bree to happily singing fowl in Rivendell) or the sounds made by characters (Tom Bombadil, for instance, whistles 'like a tree full of birds'). ${ }^{1}$ Tolkien also appeals to animal imagery when he describes the characters themselves: the creature Gollum, for instance, is explicitly referred to as 'a spider himself, or perhaps more like a starved frog.' Paul J. Smith has convincingly suggested that this last reference to Gollum as

1 Lehn, Antje vom, "Animals in The Hobbit and The Lord of the Rings", in Zon, Cécile van - Vink, Renée (eds.), Lembas Extra Edition 2015: Unexplored Aspects of Tolkien and Arda (Soest: 2015) 191-222.

2 Tolkien, J.R.R., The Lord of the Rings (London: 1954-1955), bk. 4, ch. 10. This work is available in so many different editions, that I will refer to book and chapter numbers rather than page numbers.

(C) THIJS PORCK, 2022 | DOI:10.1163/9789004472013_021

This is an open access chapter distributed under the terms of the CC BY 4.0 license. 
a frog may ultimately stem from Tolkien's gallophobia. ${ }^{3}$ In this article, I will argue that the former reference to Gollum, as a spider, was partly inspired by the medieval bestiary tradition with which Tolkien was intimately familiar.

As Smith, along with many other Tolkien scholars, ${ }^{4}$ has demonstrated, exploring the academic sources of Tolkien's fiction can shed new light on how this Oxford Professor of Anglo-Saxon constructed a medievalist fantasy world. Many of Tolkien's motifs, characters and writing techniques were inspired by his lifelong study of medieval language and literature. By surveying the interaction between Tolkien's medieval sources and his literary work, researchers have been able to better understand how Tolkien wrote and how he managed to create a secondary world that is quintessentially Northern and medieval but also appeals to a globally expanding, modern audience. ${ }^{5}$ While much of Tolkien source criticism has focused on well-known texts such as Beowulf, there is still a range of medieval texts that have only rarely been surveyed in relation to Tolkien's fiction. ${ }^{6}$ Two such relatively under-researched texts are the focus of this contribution: the Old English and Middle English versions of Physiologus.

These two texts are vernacular versions of the medieval bestiary tradition that started with the Greek text Physiologus (c.200 AD). This text featured the natural behaviour (the natura) of forty-nine animals, plants and stones, each accompanied by an allegorical interpretation (the significatio). The text was soon translated into Latin and sparked off many adaptations in Latin and medieval vernaculars, with more and more animals added as the tradition grew and expanded throughout medieval Europe. ${ }^{7}$ Two medieval English translations of a Latin Physiologus text survive: an Old English fragment of only 179 lines (covering the panther, whale and partridge) and an independent, Middle English version, surviving only in one manuscript, that describes thirteen animals. ${ }^{8}$

3 Smith, Paul J., "French Connections in Middle-earth: The Medieval Legacy", in Kuijpers, Nathalie - Vink, Renée - Zon, Cécile van (eds.), Tolkien among Scholars (s.l.: 2017) 134.

4 See Smith, "French Connections". For other examples of source criticism applied to Tolkien, see the contributions to Fisher, Jason (ed.), Tolkien and the Study of His Sources: Critical Essays (Jefferson, NC: 2011); Porck, Thijs, "De Middeleeuwen in Midden-aarde: J.R.R. Tolkien en zijn Oudengelse inspiratiebronnen”, in De populaire Middeleeuwen, special issue Madoc. Tijdschrift over de Middeleeuwen 32 (2018) 195-205.

5 See, e.g., Shippey, Tom, The Road to Middle-Earth:How J.R.R. Tolkien Created a New Mythology, 3rd edition (London: 2003).

6 Porck, Thijs, "New Roads and Secret Gates, Waiting around the Corner: Investigating Tolkien's Other Anglo-Saxon Sources," in Kuijpers - Vink - van Zon, Tolkien among Scholars 49-64.

7 For an introduction to the tradition, see McCulloch, Florence, Medieval Latin and French Bestiaries (Chapel Hill: 1962).

8 The Middle English version is based on the Latin Physiologus by Theobald, but it deviates significantly from its source text in places, including in its entry for the Spider. See Cavell, Megan, "Arachnophobia and Early English Literature", New Medieval Literatures 18 (2018) 35-40. 
Tolkien is known to have read these texts and referred to them in some of his writings. ${ }^{9}$

As I will demonstrate below, Tolkien draws on the Old English and Middle English versions of Physiologus for his poems "Fastitocalon" and "Iumbo, or ye Kind of ye Oliphaunt", which were first published in 1927 under the joint title of Adventures in Unnatural History and Medieval Metres, Being the Freaks of Fisiologus. ${ }^{10}$ The description of the Elephant in the Middle English Physiologus is directly preceded by a unique description of the Spider, which possibly influenced Tolkien's characterisation of spiders in The Lord of the Rings.

A Whale Turned Turtle: Tolkien's "Fastitocalon"

During a lecture on medieval poetry, Tolkien once presented his audience with a verse composition of his own. According to Richard C. West, he explained this act as follows:

Professor Tolkien said himself that his medieval studies fertilized his imagination, that his typical response upon reading a medieval work was to desire not so much to make a philological or critical study of it as to write a modern work in the same tradition. ${ }^{11}$

Indeed, Tolkien's literary output includes various imitations of medieval genres, ranging from Gothic drinking songs and Breton lays to Old English annals. ${ }^{12}$ His 1927 Adventures in Unnatural History and Medieval Metres are clearly imitations of the medieval bestiary tradition.

$9 \quad$ He refers to the Old English Physiologus in one of his letters; Tolkien, J.R.R., The Letters of J.R.R. Tolkien, ed. Humphrey Carpenter with the assistance of Christopher Tolkien (London: 1981) no. 255. The Middle English Physiologus is referred to in his article on Chaucer's Reeve's Tale as well as in his Exeter College Notebooks; Cilli, Oronzo, Tolkien's Library: An Annotated Checklist (Edinburgh: 2019) 18.

10 Stapledon Magazine 7 (June 1927). The texts are reproduced in Tolkien, J.R.R., The Adventures of Tom Bombadil and Other Verses from The Red Book, ed. Scull, Christina Hammond, Wayne G. (London: 2014) 216-220, 224-227. Two further bestiary entries, entitled "Reginhardus, the Fox" and "Monoceros, the Unicorn" (cognate with Chapters XVIII and XXXvI of the Latin Physiologus) remain unprinted. Rateliff, John D., "Inside Literature: Tolkien's Explorations of Medieval Genres", in Houghton, John Wm. - Croft, Janet Brennan - Martsch, Nancy - Reid, Robin Anne (eds.), Tolkien in the New Century: Essays in Honor of Tom Shippey (Jefferson, NC: 2014) 148, n. 16.

11 West, Richard C., "The Interlace Structure of The Lord of the Rings", in Lee, Stuart (ed.),J.R.R. Tolkien: Critical Assessments of Major Writers (London - New York: 2017) III, 180, n. 10.

See Rateliff, "Inside Literature" 133-152. 
His poem "Fastitocalon", for instance, is divided into the two traditional parts, a natura and a significatio. ${ }^{13}$ In the first part, Tolkien describes how the whale, called Fastitocalon, lures smaller fishes into its jaws through the sweet sound of its singing (rather than through its sweet smell as the Physiologus tradition would have it); next, in line with the Physiologus tradition, it describes how sailors mistake the whale for an island and, standing upon its back, proceed to make fires, causing the whale to dive under water and drown the sailors. The poem is clearly intended as a parody, since it features comical references to whale's blubber ('OLD Fastitocalon is fat: / His grease the most stupendous vat') and how the sailors intended to brew some tea on the back of the whale ('If any one lands there / with kettle / To make a picnic tea, or get / Relief from sickness or the wet, / Or some, perhaps, to settle'). The significatio is also an attempt at humour. Rather than the medieval interpretation of the whale as representing the lures of the devil, Tolkien's Fastitocalon stands for the dangers of trespassing, especially when one's interests are peeked by loud music:

This mighty monster teaches us

That trespassing is dangerous,

And perils lurk in wait

For curious folk who peep in doors

Of other folk, or dance on floors

$[\ldots]$

That many noises loud and strong

Are neither music nor a song

But only just a band.

The allegorical interpretation here deals more with the lure of the whale's singing (an invention of Tolkien's) than the original moral's focus on the untrustworthiness of the devil as symbolized by the sinking island.

John D. Rateliff has touched upon the relationship of "Fastitocalon" to the Old English and Middle English Physiologus. ${ }^{14}$ He notes that the title certainly derives from the Old English version, since Tolkien admitted as much in a letter (referring to a strongly reduced version of the poem with the same title that was published as part of The Adventures of Tom Bombadil, for which, see below):

The poem on Fastitocalon is not [...] my own invention entirely but a reduced and rewritten form, to suit hobbit fancy, of an item in old

13 All quotations from this poem are from Tolkien, Adventures 224-227.
14 Rateliff, "Inside Literature" 136-137. 
'bestiaries'. [The name] I took in fact from a fragment of an Anglo-Saxon bestiary that has survived..$^{15}$

Despite Tolkien's explicit reference to the Old English Physiologus here, Rateliff suspects that the Middle English version may nevertheless have influenced the 1927 poem as well. He notes that the order of the natura (first the luring of the small fishes; then the mimicking of an island) is unlike that of the Old English version, but follows that found in the Middle English Physiologus and its Latin source. ${ }^{16}$ Rateliff's suspicion can be confirmed by the presence in Tolkien's poem of a description of why the whale leaves the ocean floor and comes to the surface, which has a parallel in the Middle English version:

Yet are there times of storm and strife,

When equinoctial gales are rife,

And there is much ado

down there.

He finds the depths devoid of rest,

Then up He comes and on His chest

Floats in the upper air.

til it cumeð ðe time

ðat storm stireð al ðe se,

[...]

So droui is te sees grund,

ne mai he wunen ðer ðat stund,

oc stireð up and houeð stille;

wiles ðar weder is so ille, ${ }^{17}$

This detail is not in the Old English version, which suggests that Tolkien based it on the Middle English instead.

A highly reduced version of the poem "Fastitocalon" was included in The Adventures of Tom Bombadil, which Tolkien describes as a set of Hobbit poems

\footnotetext{
15 Tolkien, Letters no. 255.

16 Rateliff, "Inside Literature" 147, n. 14.

17 'Until the time comes that the storm stirs up the entire sea ... so troubled is the bottom of the sea that he cannot remain there that time. But he swims up and remains still, while the weather is so ill there'. Middle English Physiologus, 1l. 519-520, 523-526. The edition used here is the one that Tolkien would have been familiar with: Morris, Richard (ed.), Early English Bestiary based on the Latin Physiologus of Theobaldus Episcopus (London: 1848). The translation is my own.
} 
that were added to the margins and on loose leaves in the fictional Red Book of Westmarch. According to Tolkien's introduction to The Adventures of Tom Bombadil, this version of the poem is attributed to none other than Samwise Gamgee: 'No. 11 ["Fastitocalon"] is also marked sG, though at most Sam can only have touched up an older piece of the comic bestiary lore of which Hobbits appear to have been fond.'18 Sam's version is indeed a shortened version of the original 1927 poem: it leaves out the first part of the natura about the whale luring fishes through its singing and much of the diction has been simplified. The significatio has been retained but now no longer makes mention of music, warning instead against exploring uncharted territories ('Pay heed to sailors' ancient lore, / Set foot on no uncharted shore!'). ${ }^{19}$

Another crucial difference with the 1927 poem is that the titular beast in The Adventures of Tom Bombadil is no longer a whale, but 'the last of the great Turtle-fish'. Tolkien explains this choice, as well as the odd name for the beast in the Old English Physiologus, in the same letter as the one cited above:

The learned name in this case seems to have been Aspido-chelone 'turtle with a round shield (of hide)'. Of that astitocalon is a corruption no worse than many of the time; but I am afraid the F was put on by the versifier simply to make the name alliterate, as was compulsory for poets in his day, with the other words in his line. Shocking, or charming freedom, according to taste.

He says: pam is noma cenned / fyrnstreama geflotan Fastitocalon, 'to him is a name appointed, to the floater in the ancient tides, Fastitocalon. The notion of the treacherous island that is really a monster seems to derive from the East: the marine turtles enlarged by myth-making fancy; and I left it at that. But in Europe the monster becomes mixed up with whales, and already in the Anglo-Saxon version he is given whale characteristics, such as feeding by trawling with an open mouth. In moralized bestiaries he is, of course, an allegory of the Devil, and is so used by Milton. ${ }^{20}$

The change from whale in the 1927 poem to asp-turtle in the Hobbit poem reflects Tolkien's interests in the origins of words and names, and how this interest in etymology affected the way he wrote and rewrote his works. ${ }^{21}$

\footnotetext{
18 Tolkien, Adventures 3 o.

19 All quotations from this poem are from Tolkien, Adventures 9o-92.

$20 \quad$ Tolkien, Letters no. 255 .

21 On Tolkien and etymology, see, e.g., Weiner, Edmund - Marshall, Jeremy - Gilliver, Peter, The Ring of Words: Tolkien and the Oxford English Dictionary (Oxford: 2006).
} 
Tolkien's second parodic bestiary entry deals with the elephant. A typical Physiologus entry for the elephant dwells at length on the fact that elephants do not copulate unless the female elephant introduces the male to the root of the mandrake. Induced by this drug, the elephants produce offspring; labour takes place inside a lake, since the mortal enemy of the elephant, the serpent or dragon, does not like water. Next the typical bestiary entry talks about how elephants have no knee joints and cannot stand up by themselves. Therefore, they sleep whilst resting against trees. Hunters intent on capturing the beast will partially cut through the trees, so that the elephant, unsuspectingly leaning against it, will topple over. Fellow elephants are assembled through loud trumpeting noises, until a baby elephant manages to upright the toppled elephant with its trunk. In the typical significatio of a medieval bestiary, the female's offering of the mandrake is linked to Eve offering the apple to Adam and the baby elephant is Christ who humbled himself so as to lift up fallen mankind. ${ }^{22}$

Tolkien's 1927 poem "Iumbo, or ye Kind of ye Oliphaunt" retains some of these traditional elements. ${ }^{23} \mathrm{He}$ notably leaves out any reference to copulation, but he does dwell on the effects of the mandrake root; according to his poem, this drug would make elephants go mad and go on a rampage, causing them to throw down houses. The poem includes references to the elephant resting against a tree that is cut through by hunters ('For hunters all too well / Acquainted with his little habits lurk / Beneath the Upus' shade; a nasty sell / For Oliphas they plan, his funeral knell'), as well as the notion that elephants cannot get up by themselves ('Then frightful fear amid his exaltation / Awakes within him lest he tumble flat, / For apparatus none for levitation / Has he, who falling down must feebly bat / The air with legs inadequate and fat.'). The moral significatio has lost much of its Christian references and dwells on the fact that one should not take drugs, but indulge in wine instead:

Not music nor fat feeding make a feast

But wine, and plenty of it. Good men wink

At fun and frolic (though too well policed)

When mildly canned or innocently greased;

But those whose frenzy's root is drugs not drink

Should promptly be suppressed and popped in clink.

22 McCulloch, Bestiaries 115-119.

23 Quotations from this poem are taken from Tolkien, Adventures 216-220. 
Again, the sardonic significatio makes clear that the intention of this poem is parody.

The opening lines of Tolkien's poem show the influence of the Middle English Phsyiologus:

\section{Natura iumbonis}

The Indic oliphaunt's a burly lump,

A moving mountain, a majestic mammal

\section{Natura elephantis \\ Elpes arn in Inde riche, \\ on bodi borlic berges ilike ${ }^{24}$}

The phrases 'burly lump' and 'moving mountain' clearly appear inspired by the first lines of the entry for elephant in the Middle English Physiologus. The remainder of "Iumbo, or ye Kind of ye Oliphaunt" covers some elements of the contents of the Middle English Physiologus, as noted above, but shows very little lexical influence. Instead, Tolkien uses a more modern and notably polysyllabic vocabulary in this poem with such obscure and bloated words as 'unmasticated', 'unconvivial', 'pharmaceutic' and 'brobdingnagian'.

The 1927 poem on the elephant is nothing like the "Oliphaunt" poem that eventually found its way into The Lord of the Rings, where it is recited by Samwise Gamgee, ${ }^{25}$ and The Adventures of Tom Bombadil, where it is included in the same form. Of this later version of Tolkien's "Oliphaunt", Paul Smith has remarked that this 'old fireside rhyme of Oliphaunt has rightly been interpreted as a popular version of a twelfth- or thirteenth-century Latin or French (or Anglo-Norman) bestiary'. ${ }^{26}$ Be that as it may, the poem "Oliphaunt" retains little of Tolkien's arguably more bestiary-like poem "Iumbo, or ye Kind of ye Oliphaunt". The bestiary format with a natura and significatio is gone, as are the typical details from the Physiologus tradition (the elephant's inability to stand up by itself; the hunters cutting down their resting trees; and their love for the mandrake).

Instead, Tolkien appears to have relied on Old English traditions for his "Oliphaunt" poem as well as the overall description of the Oliphaunts in The Lord of the Rings. For instance, Rateliff has noted how "Oliphaunt" adopts the

\footnotetext{
24 'The nature of the elephant. There are many elephants in India, in a burly body like a mountain'. Middle English Physiologus, ll. 603-6o5.

25 Tolkien, Lord of the Rings bk 4, ch. 3.

26 Smith, "French Connections" 127.
} 
form of an Old English riddle, in which a first-person speaker describes himself in a circumvent manner. ${ }^{27}$ In addition, some of the details about the physical appearance of elephants in "Oliphaunt" and the manner in which they are used in battles in The Lord of the Rings are not drawn from the Middle English Physiologus, but, instead, have almost exact parallels in a number of Old English homilies, as I have discussed elsewhere. ${ }^{28}$

A Deadly Female Spider and Deceitful Spidermen: Spiders in The Lord of the Rings

The description of the elephant in the Middle English Physiologus is immediately preceded by an elaborate description of the spider. As Megan Cavell has noted, this Middle English description is unique within the medieval bestiary tradition and deviates substantially from its immediate Latin source, the Physiologus by Theobald. ${ }^{29}$ The two versions of the spider's natura are provided below: ${ }^{30}$

\author{
Vermis araneus exiguus \\ Plurima fila net assiduus, \\ Texere que studet artificus. \\ Retia sunt ea, musca, tibi, \\ Ut volitans capiaris ibi, \\ Dulcis et utilis esca sibi. \\ Huic placet illud opus tenue, \\ Sed sibi nil valet ut fragile: \\ Quelibet aura trahit patulum; \\ Rumpitur et cadit in nihilum. ${ }^{31}$
}

27 Rateliff, "Inside Literature" 148, n. 16.

28 Porck, Thijs, “The Medieval in Middle-earth: Anglo-Saxon Elephants and Tolkien's Oliphaunts" (o1-O3-2020), <https://thijsporck.com/2020/03/o1/oliphaunts/>.

29 Cavell, "Arachnaphobia"; the distinctive features may have been influenced by the medieval French Bestiaire attributed to Pierre de Beauvais, see idem, "Spiders Behaving Badly in the Middle English Physiologus, the Bestiaire Attributed to Pierre de Beauvais and Odo of Cheriton's Fables", Neophilologus 104 (2020) 567-583.

30 Texts and translations cited from Cavell, "Spiders".

31 'The small insect, the spider, ceaselessly spins many threads, which, expertly, it strives to weave. Those are nets for you, fly, so that you are caught there, flying, a sweet and profitable meal for it. That delicate work is pleasing to this one, but it is worth nothing to it as fragile as it is: any breeze draws it apart; it is destroyed and falls into nothing. 
Seftes sop ure Seppande, sene is on werlde, Leiðe \& lo[dl]ike, ðus we it leuen, Manikines ðing, alle manne to wissing. Đe spinnere on hire [web] swi[ðe] зe weveð, Festeð atte hus-rof, hire fo [ð]redes, O rof er on ouese, so hire if on elde, Werpeð ðus hire web, \& weueð on hire wise. Đanne ze it haueð al idizt, ðeðen ze driueð, Hitt hire in hire hole, oc ai ze it biholdeð Til ðat ðer flezes faren \& fallen ðerinne, Wiðeren in ðat web, \& wilen ut wenden. Đanne renneð ze rapelike, for $z^{\mathrm{e}}$ is ai redi: Nimeð anon to ðe net \& nimeð hem ðere. Bitterlike ze hem bit \& here bane wurðeð, Drepeð \& drinkeð here blod, doð ze hire non oðer god, Bute fret hire fille, \& dareð siðen stille. ${ }^{32}$

While Theobald's Latin version emphasizes the fragility of the spider's web, the Middle English version introduces a frighteningly fierce spider, weaving murderous webs and schemingly hiding in a hole. In addition, Cavell notes that the Middle English version uniquely introduces gendered pronouns - the Middle English spider, in contrast to the masculine Latin araneus, is explicitly referred to as a female being. ${ }^{33}$ Both Theobald and the Middle English Physiologus provide an allegorical significatio in which the spider represents deceitful men: ${ }^{34}$

Hos sequitur homo vermiculos,

Decipiendo suos socios, Quos comedit faciens miseros;

Et placet inde sibi nimium,

32 'Our creator created creatures, visible in the world, detestable and loathsome, and so we believe that many different kinds of things are for humanity's instruction. The spider on her web, she quickly weaves, fastens her variegated threads at the roof of the house, from the roof or from the eaves, as if she were on a hill, threads thus her web, and weaves it in her manner. When she has it all ready, she dashes away from there, hides in her hole, but she always looks upon it until flies come to it and fall therein, writhe in that web, and want to go out. Then she runs hurriedly, for she is always ready: immediately she steals to the net and seizes them there. Fiercely she bites them and becomes their murderer, subdues them and drinks their blood, she does for herself no other good, but eats her fill, and then sits still.'

33 Cavell, "Arachnophobia" 38.

34 Texts and translations cited from Cavell "Spiders". 
Quando nocere potest alium.

Ille tamen mala queque facit,

Cum moritur, quasi tela cadit,

Qua modo dictus araneus it. ${ }^{35}$

Đis wirm bitokeneð ðe man ðat oðer biswikeð,

On stede er on stalle, stille er lude,

In mot er in market, er oni oðer wise.

He him bit ðan he him bale selleð

\& he drinkeð his blod wanne he him dreueð

\& ðo freteð $\mathrm{h}[\mathrm{i}] \mathrm{m}$ al ðan he him iuel werkeð. ${ }^{36}$

Both the natura and the significatio of the spider in the Middle English Physiologus have arguably left their traces in The Lord of the Rings.

The Middle English Physiologus may have been a source of inspiration for Tolkien's own equally frightening feminine arachnid Shelob. The potential origins of Shelob, whose name is a combination of the pronoun she and the Old English word loppe 'spider', have been the matter of scholarly debate. ${ }^{37} \mathrm{~A}$ common hypothesis is that she is based on a traumatic childhood experience of Tolkien: he was once bitten by a spider in Bloemfontein, South Africa. Writing to W.H. Auden, Tolkien commented on this much-cited anecdote:

I knew that the way was guarded by a Spider. And if that has anything to do with my being stung by a tarantula when a small child, people are welcome to the notion (supposing the improbable, that any one is interested). I can only say that I remember nothing about it, should not know it if I had not been told; and I do not dislike spiders particularly, and have no urge to kill them. I usually rescue those whom I find in the bath! ${ }^{38}$

35 'A man follows these small insects, cheating his own companions, making them miserable he devours them; and that gives him great pleasure when he is able to harm another. Yet whatever evil that one brings about, when he dies he falls like the web, on which the aforementioned spider walks'.

$3^{6}$ 'This bug signifies the man who deceives another, in one place or another, under any circumstances, in a meeting or in the market, or in any other way. He bites him when he does him harm and drinks his blood when he troubles him and then eats him when he continually causes evil for him'.

37 See, e.g., Donovan, Leslie A., "The Valkyrie Reflex in The Lord of the Rings: Galadriel, Shelob, Eowyn and Arwen", in Chance, Jane (ed.), Tolkien the Medievalist (London: 2003) 106-132, who links Shelob to the Valkyrie of medieval Germanic tradition.

$38 \quad$ Tolkien, Letters no. 163 . 
If not a personal hatred for spiders, the negative portrayal of the bloodthirsty female spider in the Middle English Physiologus may have inspired the equally negative depiction of spiders in Tolkien's fiction. Shelob, in particular, is introduced in The Lord of the Rings with an emphasis on her bloodthirstiness and appetite, aspects of the spider that the author of the Middle English Physiologus specifically added to his Latin source:

How Shelob came there, flying from ruin, no tale tells, for out of the Dark Years few tales have come. But still she was there, who was there before Sauron, and before the first stone of Barad-dûr; and she served none but herself, drinking the blood of Elves and Men, bloated and grown fat with endless brooding on her feasts, weaving webs of shadow; for all living things were her food, and her vomit darkness. ${ }^{39}$

Shelob's hunting habits, lurking in a cave waiting for her victims to get stuck in her web, is also paralleled by the beast's description in the Middle English Physiologus. The most striking similarity between Shelob and her Middle English analogue is perhaps the specification of their gender, in both cases we are dealing with a monstrous bug whose femininity is consistently stressed. ${ }^{40}$

Shelob is not the only arachnid in The Lord of the Rings: three characters are described with spider similes. In line with the significatio of the medieval bestiary tradition, these characters are all deceitful males. When Gandalf discusses the treachery of Saruman, for instance, he appeals to the imagery of the spider, describing himself as having been 'caught like a fly in a spider's treacherous web', ${ }^{41}$ In accordance with the significatio in Theobald's Physiologus, ${ }^{42}$ Saruman's webbing turns out to be weak, leading to the unravelling of his dastardly plan: 'Yet even the most subtle spiders may leave a weak thread. ${ }^{43}$ Denethor too is described in arachnid fashion ('like an old patient spider'), when the Steward of Gondor intends to manipulate the Hobbit Pippin into giving up more information than necessary. ${ }^{44}$

39 Tolkien, Lord of the Rings bk. 4, ch. 9 .

40 For an overview of other interpretations of Shelob's gender, including those bordering on the Freudian, see Burns, Marjorie, "Shelob" in Drout, Michael D.C. (ed.), J.R.R. Tolkien Encyclopedia: Scholarship and Critical Assessment (New York - London: 2007) 6o6-6o7.

41 Tolkien, Lord of the Rings bk. 2, ch. 2.

42 Which would have been available to Tolkien via the same edition of the Middle English Physiologus by Morris, see footnote 17 .

43 Tolkien, Lord of the Rings bk. 2, ch. 2. In bk. 3, ch. 10, Gandalf refers to Saruman as 'the spider in a steel web'.

44 Tolkien, Lord of the Rings bk. 5, ch. 3 . 
The person most often linked to a spider is the creature Gollum. He is explicitly called a spider by both Samwise Gamgee ('like a nasty crawling spider on a wall') and the orc Shagrat ('like a spider himself, or perhaps more like a starved frog') ${ }^{45}$ The narrative voice refers to Gollum as a spider three times: 'like a spider whose descending thread is snapped'; 'like a cornered spider'; and 'almost spider-like he looked now, crouched back on his bent limbs, with his protruding eyes. ${ }^{46}$ This last description of Gollum as 'spider-like' comes at a crucial moment in The Lord of the Rings. Only seconds prior, Gollum had appeared 'an old weary hobbit, shrunken by the years that had carried him far beyond his time, beyond friends and kin, and the fields and streams of youth, an old starved pitiable thing'; his arachnoid transformation is the result of Sam's accusatory outburst ('But where have you been to - sneaking off and sneaking back, you old villain?') which abruptly ends an interior debate within the creature and fixes in Gollum's mind his plan to deceive the Hobbits and lead them into Shelob's trap. ${ }^{47}$ His spider-like appearance thus does not only foreshadow the encounter with Shelob later on, ${ }^{48}$ it is also a reflection of the treacherous plan that is now lodged in his brain. Ultimately, Gollum's deceit leads to his tumbling to his death after having bitten one of the companions he has cheated, not unlike the deceitful men in the significatio of the spider in both Theobald's Physiologus and its Middle English rendition.

\section{4}

\section{Conclusion}

Tolkien was not only a medievalist; he was, in many ways, like a medieval author himself. ${ }^{49}$ His 1927 poems in Adventures in Unnatural History and Medieval Metres are testimony to his familiarity with the medieval bestiary tradition, particularly the Old English and Middle English Physiologus, and his talent for producing works inspired by and imitating medieval originals. Interestingly, Tolkien's application of animal imagery in The Lord of the Rings, whereby comparisons to specific animals may have been partly motivated by their significatio in the medieval bestiary tradition, also has a medieval

\footnotetext{
45 Tolkien, Lord of the Rings bk. 4, ch. 1; bk. 4, ch. 10.

46 Tolkien, Lord of the Rings bk. 4, ch. 1; bk. 4, ch. 3; bk. 4, ch. 8.

47 Tolkien, Lord of the Rings bk. 4, ch. 8. Sam's outburst thus ruins Gollum's chances at redemption; Tolkien wrote the following about his emotional response to this scene: 'I am [...] most grieved by Gollum's failure (just) to repent when interrupted by Sam'. Tolkien, Letters no. 165 .

48 Cf. Vom Lehn, "Animals" 211.

49 Rateliff "Inside Literature".
} 
parallel. Geoffrey Chaucer, the Middle English poet whose work was another main research focus for Tolkien, ${ }^{50}$ used animal imagery in exactly the same way in his Miller's Tale and Reeve's Tale. ${ }^{51}$ As such, even the manner in which Tolkien incorporated his medieval animals into Middle-earth may have been inspired by the medieval texts he studied.

\section{Bibliography}

Bowers, John M., Tolkien's Lost Chaucer (Oxford: 2019).

Burns, Marjorie, "Shelob" in Drout, Michael D.C. (ed.), J.R.R. Tolkien Encyclopedia: Scholarship and Critical Assessment (New York - London: 2007) 606-6o7.

Cavell, Megan, "Arachnophobia and Early English Literature", New Medieval Literatures 18 (2018) 1-43.

Cavell, Megan, "Spiders Behaving Badly in the Middle English Physiologus, the Bestiaire Attributed to Pierre de Beauvais and Odo of Cheriton's Fables", Neophilologus 104 (2020) $567-583$.

Cilli, Oronzo, Tolkien's Library: An Annotated Checklist (Edinburgh: 2019).

Donovan, Leslie A., "The Valkyrie Reflex in The Lord of the Rings: Galadriel, Shelob, Eowyn and Arwen", in Chance, Jane (ed.), Tolkien the Medievalist (London: 2003) 106-132.

Fisher, Jason (ed.), Tolkien and the Study of His Sources: Critical Essays (Jefferson, NC: 2011).

Lehn, Antje vom, "Animals in The Hobbit and The Lord of the Rings", in Zon, Cécile van - Vink, Renée (eds.), Lembas Extra Edition 2015: Unexplored Aspects of Tolkien and Arda (Soest: 2015) 191-222.

McCulloch, Florence, Medieval Latin and French Bestiaries (Chapel Hill: 1962).

Morris, Richard (ed.), EarlyEnglish Bestiary based on the Latin Physiologus of Theobaldus Episcopus (London: 1848).

Porck, Thijs, "De Middeleeuwen in Midden-aarde: J.R.R. Tolkien en zijn Oudengelse inspiratiebronnen", in De populaire Middeleeuwen, special issue Madoc. Tijdschrift over de Middeleeuwen 32 (2018) 195-205.

Porck, Thijs, "New Roads and Secret Gates, Waiting around the Corner: Investigating Tolkien's Other Anglo-Saxon Sources," in Kuijpers, Nathalie - Vink, Renée - Zon, Cécile van (eds.), Tolkien among Scholars (s.l.: 2017) 49-64.

$5^{\circ} \quad$ See, e.g., Bowers, John M., Tolkien's Lost Chaucer (Oxford: 2019).

$5^{1}$ See, e.g., Richardson, Janette, Blameth nat me: A Study of Imagery in Chaucer's Fabliaux (The Hague: 1970) 95-99, 163-165. 
Porck, Thijs, "The Medieval in Middle-earth: Anglo-Saxon Elephants and Tolkien's Oliphaunts" (O1-O3-202O), <https://thijsporck.com/2020/o3/o1/oliphaunts/>.

Rateliff, John D., "Inside Literature: Tolkien's Explorations of Medieval Genres", in Houghton, John Wm. - Croft, Janet Brennan - Martsch, Nancy - Reid, Robin Anne (eds.), Tolkien in the New Century: Essays in Honor of Tom Shippey (Jefferson, NC: 2014) $133^{-15^{2}}$.

Richardson, Janette, Blameth nat me: A Study of Imagery in Chaucer's Fabliaux (The Hague: 1970).

Shippey, Tom, The Road to Middle-Earth: How J.R.R. Tolkien Created a New Mythology, 3rd edition (London: 2003).

Smith, Paul J., "French Connections in Middle-earth: The Medieval Legacy", in Kuijpers, Nathalie - Vink, Renée - Zon, Cécile van (eds.), Tolkien among Scholars (s.l.: 2017) $119-136$.

Tolkien, J.R.R., The Adventures of Tom Bombadil and Other Verses from The Red Book, ed. Scull, Christina - Hammond, Wayne G. (London: 2014).

Tolkien, J.R.R., The Letters of J.R.R. Tolkien, ed. Humphrey Carpenter with the assistance of Christopher Tolkien (London: 1981).

Tolkien, J.R.R., The Lord of the Rings (London: 1954-1955).

Weiner, Edmund - Marshall, Jeremy - Gilliver, Peter, The Ring of Words: Tolkien and the Oxford English Dictionary (Oxford: 2006).

West, Richard C., "The Interlace Structure of The Lord of the Rings", in Lee, Stuart (ed.), J.R.R. Tolkien: Critical Assessments of Major Writers (London - New York: 2017) III, 178-19o. 